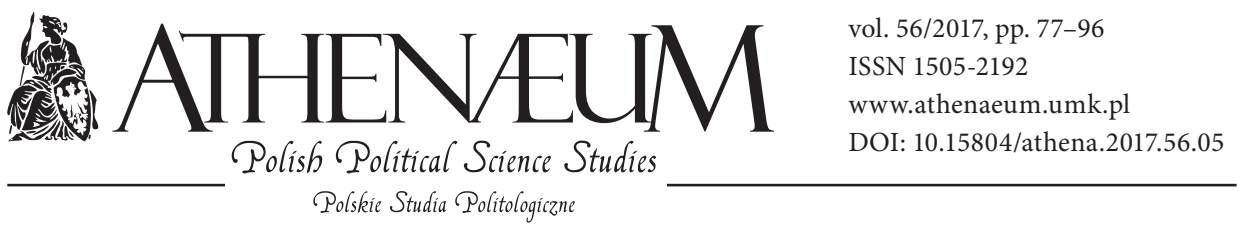

\title{
TWO BRITISH REFERENDA ON THE EU, TWO DIRECTIONS OF TRAVEL
}

\author{
DWA BRYTYJSKIE REFERENDA W SPRAWIE UE, \\ DWA KIERUNKI PODRÓŻY
}

Elżbieta Kużelewska*, Bogusia Puchalska**

\begin{abstract}
EEC/EU membership has been one of the thorniest issues in British politics over the last 45 years. The 1975 referendum confirmed the UK's will to stay in the EEC, but it failed to put to rest the argument over Europe. The 2016 referendum took Britain into the opposite direction, but it also reinstated the issue of the EU to the prime slot in British politics, where it is going to stay for the many years needed to settle the new relationship with the EU. The main drivers behind both referenda were the power struggle between the main parties and the gradual entrenchment of Euroscepticism as the dominating standpoint in British right-wing politics. The substantive concerns with EEC/ EU membership were merely a backdrop to the partisan battles leading to both referenda, but the crucial differentiating factor in 2016 was the Conservative perception of the threat posed by UKIP. The Eurozone crisis and austerity policies at home added to the potent mix of disillusion
\end{abstract}

ABSTRAKT

Członkostwo Wielkiej Brytanii w EWG/UE było jednym $\mathrm{z}$ najbardziej drażliwych problemów w polityce brytyjskiej w ciągu ostatnich 45 lat. Referendum z 1975 r. potwierdziło wolę pozostania Wielkiej Brytanii w EWG, ale nie udało mu się wyciszyć sporów na temat Europy. Referendum w 2016 r. poprowadziło Brytyjczyków w odwrotnym kierunku, niemniej przywróciło kwestię UE do naczelnego miejsca w polityce brytyjskiej, gdzie pozostanie przez wiele lat celem uregulowania nowych stosunków z UE. Głównymi powodami obu referendów były walka o władzę między partiami politycznymi i stopniowe umacnianie się eurosceptycyzmu jako dominującego punktu odniesienia w polityce brytyjskich ugrupowań prawicowych. Istotne obawy związane z członkostwem w EWG/UE stanowiły jedynie tło kampanii zwolenników, prowadzące do obu referendów, ale istotnym czynnikiem różnicującym w 2016 r. było postrzeganie przez Partię Konserwatywną zagrożeń ze

* University of Białystok, Faculty of Law.

** University of Central Lancashire in Preston, School of Law. 
among the voters, who became receptive to promises of return to past glories of the UK freed from the shackles of Brussels.

Keywords: Brexit, referendum, Euroscepticism, David Cameron, voting, political parties strony UKIP. Kryzys w strefie euro i polityka oszczędności w kraju przyczyniły się do silnego rozczarowania wyborców, którzy stali się otwarci na obietnice powrotu do chwalebnej przeszłości Zjednoczonego Królestwa, uwolnionego z kajdan narzuconych przez Brukselę.

Słowa kluczowe: Brexit, referendum, eurosceptycyzm, David Cameron, głosowanie, partie polityczne

\section{INTRODUCTION}

The main drivers behind the two nation-wide UK referenda on the EEC and EU membership, in 1975 and in 2016 respectively, cannot be reduced to just the questions that were placed on the ballot papers. The background of both reflected the complex political and economic issues dominating the EEC/EU and the UK at the time. The 1975, just three years from the official signing on, the UK was conflicted over the level of contributions that it was asked to pay - perceived as much too high; and the price of agricultural products artificially hiked by the CAP. Politically, the model of neoliberal free-markets dominating the EEC was an anathema for the Labour party.

In 2016, the main issues behind the formal in/out question were different, as was the main reason for calling the referendum in the first place. Although the growing anti-immigrant sentiments, fuelled by the tabloid press on the back of the 40 unbroken year of Euroscepticism played a vital part, the more direct reason was much closely related to changing landscape of political allegiances, which were perceived to threaten the established share of political influences. The single most important factor was the stratospheric rise of UKIP confirmed in its 2014 success at EP elections. This was followed by UKIP's excellent result in the UK general elections in 2015 where it scored almost 4 million votes, which represented $12.6 \%$ share of the overall votes cast. Under the notoriously unrepresentative "First Past the Post" voting system this result translated into just one UKIP MP, which does not alter the fact of impressive 9.5\% growth in UKIP's votes share since 2010 (Election 2015).

The following research questions were put forward in the article: 1) What were the main drivers behind both referenda? 2) Was the partisan politics and 
the Eurosceptic post-imperial nostalgia the most decisive factors driving the campaigns and determining the results of the referenda? 3) What explains such divergent results in 1975 and 2016?

\section{WHY REFERENDUM IN 1975?}

The political system in the UK is a classic example of a democracy based on representation, where the most important decisions are made by the parliament. The specificity of the British system stems from the absence of codified constitution, and the uncertainty as to its exact contents. The most common elements included in the UK Constitution are statues, common law, constitutional conventions, prerogative powers, international treaties as well as writings of the leading constitutional theorists such as Dicey, and Bagehot. Tony Wright MP suggested that "the constitution is... whatever it is at any one time and we make it up as we go along" (House of Lords, 2001-2002).

Referendum in the UK is an advisory and optional vote. The decision to conduct one is made by the parliament in every instance and follows from the accepted political option and not from the requirement of constitutional practice. The results of the referendum are advisory and are subject to interpretation by the parliament, which ultimately determines whether the will of the people expressed in the popular vote will be confirmed by authorities' decision (Foster, 2016; Bokszczanin, 2003). The place of the referendum in the British political system is determined by the facts that there is no constitutional representation of institution of direct democracy, and there is no single general law about referendum as well. Matters related to the organisation of the referendum and the rules regarding campaign are each time regulated by the relevant legal act. The EU Referendum Act that introduced the Brexit referendum, was passed by MPs at second reading on June 9,2015 by 544 in favour to 53 against (Duff, 2016).

In United Kingdom there were only three national referendums held: in 1975, on continuation of participation in the European Economic Community (Dibout, 1976), in 2011, on the change of electoral system, and in 2016, regarding the issue of continuation of EU membership. The White Paper on the referendum states that the government agrees to the referendum's binding outcome, although from a legal point of view popular vote's role was only advisory (Butler, 2001). The referendum in 1975 was proposed by the Labour Party backbenchers (Wistrich 2001). This was met with sharp criticism from the leading politicians 
of all parties. Despite this, the House of Commons adopted the Referendum Act in April 1975. The referendum in 2016 was carried out on the basis of the 2015 EU Referendum Act (Weatherill, 2016).

The decision to hold a referendum on the continuation of membership in the EEC in 1975 resulted primarily from internal problems in the Labour Party and the struggle for power between Labour and the Conservatives. Whereas in 2016 it was the result of a backbenchers rebellion over the threat of UKIP. By putting the in/out EU referendum on the table, David Cameron attempted to strengthen his position among the Conservatives backbenchers, and, by fending off the threat of UKIP, to bolster the standing of Conservatives as the governing party.

\section{BRITISH POLITICAL PARTIES REGARDING CONTINUATION OF MEMBERSHIP IN THE EEC IN 1975}

The main political parties were in conflicting positions regarding the referendum on the continuation of British membership in the Common Market. During the referendum campaign, party disciplinary voting disappeared (Dutheil de la Rochère, 1989).

The continuation of membership was advocated by the so-called proEuropean coalition formed ad hoc, which included leaders of the Labour Party, the Conservative Party, and the Liberal Party. The coalition brought together both the representatives of the opposition parties and the members of the ruling Labour Party. Within the main formations there were internal tensions regarding the speed and direction of European integration (Usherwood, 2002). Only the Liberal Party unequivocally adopted a pro-integrative attitude. On the opposing side were politicians from the left wing of the Labour Party, the majority of the trade unions and representatives of the right-wing movements from other political groups. Against United Kingsdom's's continued membership in the EEC were also peripheral parties: the Scottish National Party, the Scottish Labour Party, the Ulster Unionist Party, Plaid Cymru and the Communist Party (Pierce, Valen, Listhaug, 1983).

The idea of the referendum provoked mixed feelings in the Conservative Party, while Prime Minister Edward Heath was sceptical of this institution and maintained that the referendum would not be appropriate to carry out such a fundamental change in the political system. He supported his opinion by constitutional conventions, as well as his past political experiences (Kużelewska, 
2006). He emphasized that the parliamentary system was completely capable of making the final decision to join the EEC (Butler, Kitzinger, 1976). A number of Conservatives were reluctant to accept the presence of the United Kingdom in the Community and, although they were a minority (referred to as "Conservatives against the Treaty of Rome"), they argued in the Sunday Telegraph that conservatives should vote "no" because this way they could lead to the fall of Harold Wilson and his government (Butler, Kitzinger, 1976). Some activists of the Conservative Party wanted to be seen as a Eurosceptic fraction for whom the values of national independence and freedom were unquestionable. These groupings argued that accession could seriously compromise these principles (Alexandre-Collier, 2002). However, the majority of the Conservatives were proEuropean, especially their leaders: Edward Heath, Margaret Thatcher, elected in March 1975 as the Conservatives' leader, and William Whitelaw, her rival in the battle for leader's position (King, 1977).

In the Labour Party the situation was more complex. This resulted in a sharp division within its ranks. In April 1970, the Labour unexpectedly lost the parliamentary elections, and the Conservatives came to power. Despite Prime Minister's Harold Wilson previous initiative on the issue of membership, the moment when the Labour Party accepted its role as the opposition party, voices challenging the EEC membership became lauder. Officially, the Labour Party was not against joining the EEC, but was opposed to the terms negotiated by the conservative government: "no Entry on Tory terms" - in particular the financial terms of membership (Bidegaray, Reynié, 1998). The consequence of Labour dissatisfaction was their boycott of the European Parliament and the decision not to take-up their seats by Labour MEPs (Haahr, 1992).

In 1970, the Labour left wing representative Anthony Wedgwood Benn proposed to the Labour Party leadership to hold a referendum on the UK membership in the EEC. This idea did not meet with the recognition of party colleagues, but became a challenge for the future policy of this formation (Butler, Kitzinger, 1976). For the third time in 1972, Tony Benn (already as chairman of the party) submitted the question of referendum, which was adopted by the National Executive Committee 13:11 (King, 1977). The party's vice president, Roy Jenkins, protested against the tactics adopted by the Labourites. Firstly, in his view, the referendum should not be limited to one subject; secondly, it would lead to the division of political parties and the inconsistency of the government; and thirdly, it would probably be used as a weapon against the parliament (Butler, 1978). 
Ultimately, the decision to hold a referendum was made by Prime Minister Harold Wilson as a result of an acute split in the ruling Labour Party, which threatened party disintegration (Morel, 1993). The question that was put to the voters on June 5, 1975 was: "Do you think the United Kingdom should stay in the European Community (the Common Market)?".

\section{WHY REFERENDUM IN 2016?}

Taking the decision to hold the EU referendum places David Cameron at the centre of the debate. According to Inglehart and Norris, Cameron's decision to offer the 2016 EU membership referendum was a way of using Britain's European Union membership as a way to appease Eurosceptics within his party. Equally vital was the containment of UKIP's growing popularity within traditional Conservative electoral base. The latter was of particular relevance, since the new Conservative government formed after the May 2015 elections had only a slim majority of twelve seats. This narrow margin and the just over 11 million votes cast for the Conservatives was uncomfortably close to the almost 4 million votes for UKIP, a party that was considered of marginal importance in the 2010 general elections, securing just below 1 million votes (Elections 2010). The rise of UKIP (which is a single-issues party: taking Britain out of the EU) was not just a development that needed to be taken seriously in itself. Potentially more serious was UKIP's threat to the three main political parties. This threat has been confirmed in the referendum where the voting patterns are better explained by support for UKIP, rather than Labour. There was a very strong correlation between UKIP's support and the Brexit vote (Goodwin, Heath, 2016). This correlation suggested that Labour might be losing its electoral base to UKIP.

Based on these UKIP-related context, it is likely that one of the main drivers behind Cameron's decision was to offer the country a voice on the political issues that have been dominated by UKIP. More specifically, Cameron's objective was to arrest UKIP's electoral success by offering its voters a moderate, hence less extreme political "home" as an alternative. This was to be achieved by incorporating the UKIP political programme that promised to tackle the uncontrolled immigration from the EU, and to stand up to the bureaucratic, undemocratic and overbearing EU - a dominant in the UK perception of the EU. The expected outcome was an influx of UKIP voters to the Conservative party, and an eventual demise of UKIP. The final outcome of the June 8 general elections confirmed this 
prediction. UKIP has been wiped-out of the mainstream UK politics (Has the General Election..., 2017).

Second main driver behind Cameron's EU referendum decision, although not entirely separate from the UKIP conundrum, lies within the Eurosceptic ranks of Conservative party. The issue of Europe has been causing tensions among the Conservative backbenchers for the past 40 years. "I believe and still believe that the fact that we hadn't had a referendum on this issue for 40 years, despite the fact that the European Union was changing... was actually beginning to poison British politics - it was certainly poisoning politics in my own party" (Cameron Defends Decision..., 2016).

These tensions intensified during the Conservative-Liberal Democrats coalition due to the Lib Dems strong pro-EU position which fed into these concerns (Oliver, 2015). In summary, the second key driver behind Cameron's decision was to appease the Eurosceptic Conservative backbenchers, and to "settle" the issues of Europe, and indirectly of UKIP, both of which were consuming parliamentary and governmental attention for far too long.

Additional key factor - of a different nature - in the decision to call the referendum was the muted reception in the UK of the New Settlement for the UK Within the EU negotiated by David Cameron in the European Council. Despite the apparent success of securing satisfactory agreement on all four areas listed in Cameron's letter of November 10, 2015 (the "emergency brake" on in-work benefits, the "adjustments" on child benefits, safeguards on Eurozone area governance and the EU competitiveness), the reaction of the media was almost universally hostile. Daily Telegraph described the deal as a "slap in the face for Britain" as it was clear that the settlement will not curb migration. The tabloid press displayed a high degree of viciousness in its dismissal of the Cameron's deal as insubstantial "pile of manure" (Greenslade, 2016).

\section{THE POSITION OF BRITISH POLITICAL PARTIES REGARDING CONTINUATION OF THE EU MEMBERSHIP IN THE EU IN 2016: UKIP AND THE TABLOIDS}

There is a consensus confirming the existence of a "clear anti-EU bias among the British public" (Kellner, 2009). The main drivers behind it seems to be concerns that played a key role in the outcome of the EU referendum on June 23, 2016: British sovereignty, under threat from the power-grabbing undemocratic EU; 
and immigration, seen as threatening British national identity and culture, and also as putting strain of housing and health services, and exerting downward pressure wages and employment.

It can be argued that the growing contentiousness of the European issue over the years provided a "connective glue" to the national debate on the state of Britain's economy and Britain's role in Europe (Wallace, 2012). The specific parts that were being glued together included the flow of migrants into Britain, the Eurozone crisis, and policies of austerity at home. The party politics have been focused on scoring political points by using these issues in the main political parties' manifestos aimed at undermining the EU. Wallace asked if the Eurosceptic public opinion forces political parties to take "defensive position on EU policies", or if the political parties use the Eurosceptic rhetoric for their own political gain, and influence the public (Wallace, 2012). We suggest that these two factors are best seen as interwoven. Euroscepticism is a two-side coin - it is one of the strongest divisive issues politically and socially, but it is also one that has a strong rallying/unifying power for Eurosceptics of many political persuasions and political affiliation. The persistence and a huge political and emotive charge that is associated with Euroscepticism makes it an ideal target to be exploited for political gain. And that is what seemed to have happened: a number of politicians have whipped-up Euroscepticism over the years leading up to the June 23 referendum. Arguably, this could not have happened without the contribution of the rabidly anti-European tabloids.

It is clear that quality of the media debate influences public perception of politics (Fossum, Schlesinger, 2007). There are strong reasons to suggest that British media have been successful in infecting the British public with Euroscepticism of an aggressive variety. A contributing factor was the UK politicians' tacit acquiescence to the hostility in the UK media's style of reporting on Europe. Another, was the unavailability of any competing coverage of European matters on European level. The British people were never informed what the EU is and does. Instead, they were fed a diet of sustained, one-sided Euro-bashing (Fossum, Schlesinger, 2007). Immediately after the vote in the 2016 referendum, the top search on Google was for "What is the EU?" and "What is «Brexit»"?

The glaring absence of European-level newspapers, magazines, or TV channels arguably made it easier for the Murdoch-owned media empire to fill this gap with EU-hostile coverage. The Daily Mail and his editor-in-chief Paul Dacre contributed to this with his own brand of rabid Euroscepticism. The one-sided Euro-bashing was exacerbated by the gradual closure of British newspaper offices 
in Brussels - from six in 2005 to only three that remained open in 2012. David Rennie in his report for the Centre for European Reform (CER) explains the reason for these closures by quoting a newspaper executive - "true Eurosceptics hate Europe so much that they don't want to read about it" (Rennie, 2012). These developments made it possible to turn what should have been a conversation or a debate into a monologue, a one-sided anti-European rant of the Murdochowned papers, and the Daily Mail, the effectiveness of which has been strengthened by the scant coverage of the EU affairs in the independent printed media and the TV news services. The printed media in the UK are generally anti-European, with only some exceptions, such as The Independent and The Guardian. One of the more aggressively anti-European papers is The Sun, a Rupert Murdoch title, which is said to have a huge influence over the UK electorate. The Sun, and the Murdoch empire more generally, is widely considered as determining the final outcome of elections in the UK - the clearest example of such influence. With a circulation of 2.5 million (down from 3.5 million in 2003), The Sun is by far the most popular of the British tabloids, followed by the Daily Mail, at just under 2 million. By comparison, the quality broadsheet The Guardian sells only just over 200 thousand copies a day on average. Even the broadsheets and the TV coverage tend to veer towards the Eurosceptic in the wake of the Eurozone crisis.

The media seized on anti-European stirrings in the political debate already in the wake of the signing of the Maastricht Treaty. It is clear that both politicians and the media must have sensed in the British public a receptive audience for their Eurosceptic rhetoric at that time. More importantly, the introduction of Eurosceptic discourse into the mainstream political debate, that gradually took place a decade or so after Maastricht, legitimised it and turned it into a respectable platform, in contrast with its previous fringe position associated with the UKIP and BNP. Such a move arguably facilitated a further "hardening" of the "hard Euroscepticism", that is a fundamental opposition to political and economic integration with the EU understood as 'a principled objection to the current form of integration in the European Union on the grounds that it offends deeply held values, or more likely, is the embodiment of negative values' (Szczerbiak, Taggart, 2003). There is a strong correlation between affiliation with the Conservative party (and, most obviously, UKIP) and Euroscepticism of the "hard" variety (Clements, Nanou, 2012). However, Kopecky and Mudde critique the soft/hard distinction (2002).

The dramatic change in the British media treatment of European issues has often been described as "a journey [...] from permissive consensus to destructive 
dissent", or from "uninterested acquiescence" (Daddow, 2012) to spreading the "hard" version of Euroscepticism. However, Hooghe and Marks suggest that the level of Euroscepticism increased throughout Europe since the signing of the Maastricht Treaty (2009). This transition may be best understood as a reflection of wider changes in political discourse on Europe deployed by successive UK governments and the main political parties (Daddow, 2012). The gradual hardening of anti-Europe narrative was also reflected in the media coverage of EU-related matters, which became "hysterical" and "sensationalist", using the worst stereotypes (e.g., Daily Mail, 17 Aug. 2011, accused Germany of turning the Eurozone into a "Fourth Reich"). The politicians not only failed to counter such a tone of media reporting, but bolstered it by their own agenda: immigration and the referendum of the EU, leaving the public subjected to, in effect, a successful, concerted anti-EU propaganda campaign. This failure to counterbalance the EU debate led to accusations of politicians' complicity in "denigrating the EU for party gain" (Daddow, 2012).

In contrast to the first EU referendum, the 2016 referendum was preceded by decades of tabloid mud thrown at everything European, with the two biggest selling papers, The Sun and Daily Mail, clearly taking the lead. The reasons for this switch of sides are complex, but relate mainly to the change of ownership from Maxwell to Murdoch, who is a rabid anti-European. When asked why does he hate Europe so much, Murdoch allegedly replied: "When I go into Downing Street they do what I say; when I go to Brussels they take no notice" (Martin, 2016). This campaign intensified in spring and summer of 2016. Two days before the referendum, The Sun devoted its first 10 pages to pro-Brexit coverage. There was barely a day in the period leading to June 23 without an anti-EU headlines in Daily Mail. The same paper branded the judges of the Supreme Court "the enemies of the people" after the court decision giving the Parliament, rather than Government, the right to decide if art. 50 TEU should be triggered. The justice secretary offered only very weak defence of judicial independence, stating the principle of press freedom as a key element of liberal state (Brexit Ruling..., 2016).

The successful shaping of the Brexit narrative by the tabloids fits in the Gramsci's thesis of manufacturing "common sense". This means the creation of assumptions that draw on traditions and taken-for-granted ideas to give meanings to new developments and to suggest solutions to new problems (Hall, O'Shea, 2014. The power of common sense manufacturing lies in shaping and influencing perceptions and points of view, rather than imposing one. It works 
by aligning with the innate wisdom of common people by appearing intuitive and "obvious".

Headlines such as: Migrant Influx Is Threatening to Destroy Our Way of Life; Muslim Bus Driver 'Put Children's Lives at Risk' by Stopping for Prayer; Benefit Cheats Are Spared Jail as Fraud Numbers Rocket, arguably resulted in vast estimates of the number of immigrants, Muslims and benefit fraudsters (Beckett, 2016). The real figures are much smaller, by the perception once created is very difficult to change, as it fits with the common sense view of the majority of tabloid reading Brits.

As argued by Andy Beckett: "In an era when agreed facts are becoming rarer, and voters are increasingly impatient and distracted, but also disorientated by shock events, influencing how issues are talked about is more important than ever - possibly more important, in fact, than influencing elections" (Beckett, 2016).

The tabloid Euro-bashing clearly influenced not just the way the EU was talked about; it was successful in creating a particularly hostile reception of its policies and activities. The damage was relatively easy to inflict, as no media managed to counterbalance this with neutral, informative coverage of Europe. Positive stories related to the EU simply did not exist, not in the tabloids that dominate the media market, and not in the broadsheets. It is clear that the hard line anti-Europe media and the political class whose fortunes depend on the favourable headlines had a decisive impact on the vote in the EU referendum "the way the media covers an EU political development is more prevalent and relevant to the public than often considered in the literature" (Dursun-Ozkanca, 2011).

In light of the above, the close result of the referendum might even be seen as a positive surprise. The reality, however, point out that the EU might not have been the primary issue for many voters, instead, it seems that immigration, hardship linked to George Osborn's policies of austerity, shrinking public services and falling living standards might have been the primary drivers behind the vote to leave. The less obvious, and partly unexpected additional factors were as follows: "the cynical but failed strategy that Boris Johnson followed by heading the «Leave» campaign in an (unsuccessful) attempt to take over the Conservative party leadership, $[\ldots]$ public miscalculations by Leave voters under-estimating the impact of their actions, and the capacity of referenda to mobilize protest voting" (Inglehart, Norris, 2016). 


\section{IMPERIAL SHADE OF BRITISH EUROSCEPTICISM}

The Eurosceptic narrative employed by the "Leave the EU" campaign drew on the post-imperial nostalgia that reasserted British standing in the world as a "great trading nation" whose economy is underpinned by unmatched stability of its legal and political system. Any suggestion that trade relations outside of the EU might never match the current arrangements in terms of economic benefits for the UK are dismissed by arguments based on grandiose assertions linked directly to the post-imperial Euroscepticism. One of such arguments asserts that a number of countries, particularly British former colonies, will be very keen to sign trade deals with Britain, the rules of which will be dictated by the UK.

The strong bearing of nostalgia on the current shape of British Euroscepticism has been identified by the literature on this subject as one of the most common and pervasive threads. On the level of societal culture, the desire to bring back blue passports - as opposed to the red-cover ones introduced by the $\mathrm{EU}$, the return of imperial system of weights and measures (including money), and the reinstatement of death penalty - were the other key nostalgic drivers behind the vote to leave (Here's the Crazy Things..., 2017).

Gifford, for instance, convincingly argued that the growing Euroscepticism in Britain can be best explained by the "structural susceptibility of the British postimperial order to politics of populism" (Gifford, 2006). There seem to be number of key elements of such susceptibility: imperial mentality, British exceptionalism and national identity defined in opposition to Europe.

Imperial mentality was clearly one of the main reasons for the UK to stay outside of the three European Communities in the 1950s, stemming from the British Commonwealth - the source of Britain's power and influence on international scene. By 1963, this power and influence started to wane. The dismantling of the empire threw Britain into a post-imperial hegemonic crisis. The main aspect of this crisis related to the gap between the imperial mentality shaped over two hundred years and the reality of the physical loss of the empire, coupled with the diminishing role of Britain in the post-WWII Europe. Part of this was the weakening of the special relationship between Britain and the US that formed during the WWII. The main reason was the US pressure for Britain to be more closely involved in the European integration in 1950, 1954, 1959-1960 and after 1989 (Wallace, 1991).

Related to the imperial mentality is the concept of British exceptionalism the assertion that British political development, its history and culture, and even 
its geographical location are unique, hence antithetical to Continental Europe. Such a construction, in turn, defined British national identity as incompatible with the European one, thus providing a fertile ground for Euroscepticism to offer a narrative that allowed to reclaim Britain's special status, which had eroded by the loss of the colonies. The distinctive concept of the British state which was built on the tradition of Magna Carta and English common law, centrality of Parliamentary sovereignty was used to project Britain as "a free country confronting the unfree European Continent" (Wallace, 1991).

Those cornerstones of the British constitutional arrangements are routinely contrasted with the EU's faceless bureaucracy and the infamous "democratic deficit". In particular, the rule of law and the legality principle entrenched in the constitution since Magna Carta and the English common law - described as democratic and responsive to the concerns of the people (Steillen, 2011). The sovereignty of Parliament, an elected assembly that represents the people, is seen as the very embodiment of popular democracy. Contrast with Hugo Brady's suggestion that "lectures" on this lustrous history of the British institutions is likely to irritate the other EU MSs, which all have "stories to tell about the uniqueness of their own legal systems" (2013). Those myths of national constitutionalism have been skillfully employed by the Eurosceptics to re-invent the national identity that has been in crisis after the fall of the British empire (Wallace, 1991; Gifford, 2006).

The development of Euroscepticism meant that the deep rifts and divisions over Europe never went away, as they run through the cross sections of social, economic and political groups and affiliates. Deep and often destructive divisions on most things European affected all major political parties and became one of the permanent features of British politics with UKIP and the Conservatives leading the field. The leading Eurosceptic party is obviously UKIP, followed closely by the Conservatives, where only 10 per cent of its MPs declare themselves Europhiles, with the biggest group - potential Eurosceptics - at 49 per cent, followed by potential leavers at 21 per cent, and leavers at 11 per cent (Euroscepticism..., 2015).

It is worth reminding ourselves that the main Eurosceptic at the 1975 referendum was the Labour party and its electorate. The 2016 referendum has seen not so much a reversal of this dynamics, as some dramatic shifts that defied party lines. The overall picture of voting patterns and political allegiances was complex, and it is beyond the scope of this paper to discuss it more fully. One crucial negative correlation was that between significant number of traditional Labour 
voters who opted for "Leave" despite the Labour party campaign for "Remain". There was a positive link between the majority of Conservatives voting to leave the EU and the more than 90 per cent of UKIP votes.

\section{THE DRIVERS BEHIND THE 2016 REFERENDUM RESULT}

In contrast to the first EEC referendum in 1975, the 2016 one presents a much more complex and unclear picture as to the reasons and politics behind it. Even more challenging would be to map the voting patterns on the map of party allegiances - as explained above. One of the key reasons behind this lack of clarity was the nature of arguments used by the two sides of the campaign - Vote Leave appealed to patriotic imperial nostalgia, to revive the UK as the world trading nation but removing the shackles of the EU, and regaining full sovereignty over its laws and borders. These were the typical native, populists' arguments made without much attention given to the details or the factual accuracy (Doherty, 2016). The infamous quip of Michael Gove that people are fed up by experts telling them what to do, advanced the post-truth politics where the people know that they are being fed lies, but they do not care, or mind.

We should not forget the impact of personal ambitions of politicians such as Boris Johnson, who saw the referendum as a unique opportunity to take their own career right to the top job of the Prime Minister. This is obviously nothing new, as momentous events of this kind are always likely to be exploited for a personal political gain. However, the potent mix of tabloid-stoked aggressive Euroscepticism and imperial nostalgia with the lack of impartial evidence-based information might have bolstered the existing popular appeal of Boris Johnson in an unprecedented way. It seems that this combination unleashed a potent response of the electorate which surprised even the main players on the Leave side.

The Remain campaign, on the other hand, tried to frighten British people by making very dark predictions of a total economic demise of the UK outside the EU - refer to as "project fear" by the Leavers. There was very little information about the actual, measurable benefits of the EU membership, nor much mention of the less tangible ones. Nor was there any rational, evidence based discussion of the EU disadvantages. Such discussion is yet to take place, even as the actual shape of the Post-Brexit UK is slowly emerging in the wake of Theresa May's letter of March 29, 2017 to Donald Tusk, formally triggering art. 50 TEU. 


\section{HOW DID THE BRITISH VOTE IN 1975 AND 2016?}

In the 1975 UK referendum, $67 \%$ voted in favour of remaining in the EEC. The distribution of votes in the whole country was in principle uniform. Of the 68 constituencies or counting areas of the UK only two, both Scottish, rejected the continuation of membership - in the Shetland Islands, where $43.7 \%$ voted in favour, and in the Hebrides (the Western Isles), where 29.5\% voted "Yes". This was in line with the general tendency of more support for continued membership in the south rather than in the north. Orkney and Shetland, as well as the Western Isles are the least populated parts of United Kingdom. In Shetland, there are less than 13,000 registered voters, and in the Hebrides only 22,000. Probably Shetland inhabitants voted against the EEC because they felt like a separate community, more akin to the Scandinavian (Norse) sailors rather than contemporary Scots. In addition, their anxiety was intensified by the future of the fishing industry. In turn, the inhabitants of the Western Isles were heavily influenced by the Scottish National Party and its leader, Donald Stewart (King, 1977).

Table 1. Results of British Referenda in 1975 and 2016 on EEC/EU

\begin{tabular}{|l|c|c|c|}
\hline \multicolumn{1}{|c|}{ 1975 referendum } & "Yes" votes (\%) & "No" votes (\%) & Turnout (\%) \\
\hline England & 68,7 & 31,3 & 64,6 \\
\hline Scotland & 58,4 & 41,6 & 61,7 \\
\hline Wales & 66,5 & 33,5 & 66,7 \\
\hline Northern Ireland & 52,1 & 47,9 & 47,4 \\
\hline UK (overall) & 67,2 & 32,8 & 64,5 \\
\hline Final results & 62,3 & 32,7 & 64 \\
\hline 2016 referendum & "Yes" votes (\%) & "No" votes (\%) & Turnout (\%) \\
\hline England & 46,8 & 53,2 & 64,6 \\
\hline Scotland & 62 & 38 & 61,7 \\
\hline Wales & 48,3 & 51,7 & 66,7 \\
\hline Northern Ireland & 52,1 & 47,9 & 47,4 \\
\hline UK (overall) & 55,7 & 44,3 & 64,5 \\
\hline Final results & 48,1 & 51,9 & 72,2 \\
\hline
\end{tabular}

Source: Butler \& Kitzinger, 1976; King, 1977; Leave or Remain EU Referendum Results and Live Maps (2016); The Electoral Commission (2017). 
The referendum on continuation of British membership in EEC turned out to be a nationwide victory: England voted "Yes", Wales voted "Yes", Scotland voted "Yes", and even Northern Ireland voted "Yes", although it was the region with the lowest support for remaining in European structures (52.1\%) and with the lowest voter turnout (47.4\%). The highest turnout was in Wales (66.7\%), with the highest number of euro-enthusiasts recorded, alongside England. It is also worth noting that the greatest number of void votes were cast in industrial districts, which were a natural backbone of the Labour Party. Casting invalid vote can be interpreted as an expression of opposition to government policy (Bristow, 1975). In turn, in 2016 only Scotland and Northern Ireland voted in favour of remaining in the EU (Uberoi, 2016).

\section{CLOSING REMARKS}

The 1975 referendum did not fulfil the hopes of its initiators - it did not solve the internal problems of the Labour Party. The Labour Party's position on participation in the Common Market remained non-uniform, which fuelled future internal conflicts and partially contributed to the split of the party and the birth of the Social Democratic Party in 1981. The Labour Party represented heterogeneous standpoint also towards further integration efforts (Baker, Gamble, Randall, Seawright, 2002).

The diverse drivers behind the two referenda reflect the two very different Britain - the 1975 one, which saw a clear economic benefit in joining, despite Labour's fear of the neoliberal free trade policies promoted by the EEC; and the 2016 one, tired of austerity at home, not helped by the flow of migrants, and witnessing the dream of EU economic prosperity dissolving in the Eurozone crisis. The post-imperial nostalgia embodied in the wish for the return of blue-cover passports, imperial system of weights and measures, and even the reinstatement of the death penalty played an important role in the vote for Brexit. But the most dangerous post-imperial delusion seems to be the desire to regain the global position of power and influence. Outside the EU, and with Trump in the White House, Britain has already lost a quantum of her power as the bridge between the EU and the US.

More than six months after the results were counted, the meaning of Brexit remains unclear. There are a number of reasons behind it. First of all, the government failed to produce a plan outlining what options would be available in case 
Vote Leave wins. The only legal document, the EU Referendum Act 2015, did not contain any details, or even board guidelines on the UK's future outside of the EU (Uberoi, 2015): the question on the ballot paper reduced a number of issues into one - to stay in or to leave the EU. Such choice of question opened the door to speculations and double guesses. It was in stark contrast to Scottish government which had published a 670-page White Paper outlining in detail potential shape of independent Scotland (Scotland's Future, 2013).

Not clear what the vote was for - even less clear is the type of outcome that will satisfy the "leave the EU" imperative.

\section{REFERENCES:}

Alexandre-Collier, A. (2002). Le phénomène eurosceptique au sein du Parti Conservateur britannique. Politique européenne, 2(6), 53-73.

Baker, D., Gamble, A., Randall, N., Seawright, D. (2002). Cast from the Same ProEuropean Mould? The Attitudes of Labour Members of the House of Commons, Scottish Parliament and Welsh Assembly Towards Europe. Politique européenne, 2(6), 90-113.

Beckett, A. (2016). Revenge of the Tabloids. Retrieved from: https://www.theguardian. com/media/2016/oct/27/revenge-of-the-tabloids-brexit-dacre-murdoch.

Bidegaray, Ch., Reynié, D. (1998). “A travers le miroir” La perception de la construction européenne et de son evolution par les opinions publiques dans les états membres de l'Union européenne. In: J. Rideau (ed.), La transparence dans l'Union européenne. Mythe ou principe juridique? (p. 21-78). Paris: LGDJ.

Bokszczanin, I. (2003). Referendum w Wielkiej Brytanii. In: E. Zieliński, I. Bokszczanin, J. Zieliński (eds.), Referendum w państwach Europy (p. 325-345). Warszawa: AspraJR.

Brady, H. (2013). Britain's 2014 Justice Opt-Out. Why It Bodes Ill for Cameron's EU Strategy?. Retrieved from: http://www.cer.eu/sites/default/files/publications/attachments/pdf/2013/final_brady_jha_20march13-7124.pdf.

Brexit Ruling: Lord Chancellor Backs Judiciary Amid Row. (2016). Retrieved from: http:// www.bbc.co.uk/news/uk-politics-37883576.

Bristow, S.L. (1975). Partisanship, Participation and Legitimacy in Britain's EEC Referendum. Journal of Common Market Studies, 14(4), 297-310. DOI: 10.1111/j.1468-5965.1976.tb00938.x.

Butler, D. (1978). United Kingdom. In: D. Butler, A. Ranney (eds.), Referendums. A Comparative Study of Practice and Theory (p. 211-219). Washington: American Enterprise Institute for Public Policy Research.

Butler, D. (2001). Referendums in Northern Europe. In: F. Hamon, O. Passelecq (eds.), Le référendum en Europe. Bilan et perspectives. Actes du colloque organisé les 28-29 janvier 2000 à la Maison de l'Europe de Paris (p. 60-73). Paris: L'Harmattan. 
Butler, D., Kitzinger, U. (1976). The 1975 Referendum. London: Basingstoke.

Cameron Defends Decision to Call Brexit Referendum. (2016). Retrieved from: http:// www.bbc.co.uk/news/uk-politics-38261534.

Clements, B., Nanou, K. (2012). What Underlies Public Attitudes Towards the Constitutionalisation of the EU? Evidence from Britain. Journal of Contemporary European Research, 8(4), 428-450.

Daddow, O. (2012). The UK Media and "Europe": from Permissive Consensus to Destructive Dissent. International Affairs, 88(6), 1219-1236.

Dibout, P. (1976). Référendum et système parlementaire: Etude de la consultation référendaire du 5 juin 1975 dans le Royaume-Uni. Revue Internationale de Droit Comparé, 28(2), 291-323.

Doherty, M. (2016). Should Making False Statements in a Referendum Campaign Be an Electoral Offence? Retrieved from: https:/ukconstitutionallaw.org/2016/07/04/ michael-doherty-should-making-false-statements-in-a-referendum-campaign-bean-electoral-offence/.

Duff, A. (2016). After Brexit: A New Association Agreement Between Britain and Europe. Retrieved from: www.policy-network.net/publications_download.aspx?ID=9435.

Dursun-Ozkanca, O. (2011). European Union Enlargement and British Public Opinion: The Agenda-Setting Power of the Press. Perspectives on European Politics and Society, 12(2), 139-160.

Dutheil de la Rochère, J. (1989). Le référendum en Grande-Bretagne. Les Cahiers constitutionnels de Paris I, 63-68.

Election 2010. (2010). Retrieved from: http://news.bbc.co.uk/1/shared/election2010/ results/.

Election 2015. (2015). Retrieved from: http://www.bbc.co.uk/news/election/2015/ results.

European Union Referendum Act 2015. (2015). Retrieved from: http://www.legislation. gov.uk/ukpga/2015/36/contents/enacted.

Euroscepticism in the Conservative Party: the Role of Nationalism and Electoral Pressures. (2015). Retrieved from: http://blogs.lse.ac.uk/brexit/2015/12/31/ euroscepticism-in-the-conservative-party-the-role-of-nationalism-and-electoralpressures/.

Ewing, K.D. (2001). Transparency, Accountability and Equality: The Political Parties, Elections and Referendums Act 2000. Public Law. Autumn, 542-570.

Fossum, J.E., Schlesinger, P. (2007). The European Union and the Public Sphere: A Communicative Space in the Making? In: J.E. Fossum, P. Schlesinger (eds.), The European Union and the Public Sphere: A Communicative Space in the Making? (p. 1-20). Routledge, Oxon: Routledge.

Foster, N. (2016). On the Second UK Referendum on EU Membership. Retrieved from: http://global.oup.com/uk/orc/law/eu/eulaw/resources/updates/.

Gifford, C. (2006). The Rise of Post-Imperial Populism: The Case of Right-Wing Euroscepticism in Britain. European Journal of Political Research, 45(5), 851-869. DOI: $10.1111 /$ j.1475-6765.2006.00638.x. 
Goodwin, M.J., Heath, O. (2016). The 2016 Referendum, Brexit and the Left Behind: An Aggregate-level Analysis of the Result. The Political Quarterly, 87(3), 323-332. DOI: 10.1111/1467-923X.12285.

Greenslade, R. (2016). Most of the National Press Lashes David Cameron's EU "settlement". Retrieved from: https://www.theguardian.com/media/greenslade/2016/ feb/03/most-of-the-national-press-lashes-david-camerons-eu-settlement.

Haahr, J.H. (1992). European Integration and the Left in Britain and Denmark. Journal of Common Market Studies, 30(1), 77-100.

Hall, S., and O'Shea, A., (2014). Common-sense neoliberalism. In: S. Hall, D. Massey. M. Rustin (eds), After Neoliberalism? The Kilburn Manifesto (pp. 52-68). London: Lawrence \& Wishart.

Has the General Election 2017 Finished UKIP? (2016). Retrieved from: http://www. newstatesman.com/politics/june2017/2017/06/has-general-election-2017-finishedukip.

Here's the Crazy Things Brexiteers Want to Bring Back (from Caning to Shillings). (2017). Retrieved from: http://metro.co.uk/2017/03/29/heres-the-crazy-things-brexiteerswant-to-bring-back-from-caning-to-shillings-6541331/.

Hoogh, L., Marks, G. (2009). A Postfunctionalist Theory of European Integration: From Permissive Consensus to Constraining Dissensus. British Journal of Political Science, 39(1), 1-23.

House of Lords $1^{\text {st }}$ report of 2001-1, para. 19.

Inglehart, R., Norris, P. (2016). Trump, Brexit, and the Rise of Populism: Economic Have-Nots and Cultural Backlash. HKS Faculty Research Working Paper No. RWP16-026, 1-57.

Kellner, P. (2009). Britain's Oddest Election? The Political Quarterly, 80(4), 469-478.

King, A. (1977). Britain Says Yes. The 1975 Referendum on the Common Market. Washington: American Enterprise Institute for Public Policy Research.

Kopecky, P., Mudde, C. (2012). The Two Sides of Euroscepticism: Party Position on European Integration in East Central Europe. European Union Politics, 3(3), 297-326.

Kużelewska, E. (2006). Referendum w procesie integracji europejskiej. Warszawa: AspraJR.

Leave or Remain EU Referendum Results and Live Maps (2016). Retrieved from: http:// www.telegraph.co.uk/news/0/leave-or-remain-eu-referendum-results-and-livemaps/.

Martin, B. (2016). Robert Murdoch: "I don't ask for anything from any prime minister". Retrieved from: http://www.telegraph.co.uk/business/2016/12/19/rupert-murdochdont-ask-anything-prime-minister/.

Morel, L. (1993). Party Attitudes Toward Referendums in Western Europe. West European Politics, 16(3), 225-243.

Oliver, T. (2015). To Be or Not to Be in Europe: Is That the Question? Britain's European Question and an in/out Referendum. International Affairs, 91(1), 77-91. DOI: 10.1111/1468-2346.12187. 
Pierce, R., Valen, H., Listhaug, O. (1983). Referendum Voting Behaviour: The Norwegian and British Referenda on Membership in the European Community. American Journal of Political Science, 27(1), 43-63.

Rennie, D. (2012). The Continent or the Open Sea. Does Britain have a European Future?. Retrieved from: http://www.cer.eu/sites/default/files/publications/attachments/pdf/2012/rp_096_km-6277.pdf.

Scotland's Future. (2013). Retrieved from: http://www.gov.scot/resource/0043/00439021. pdf.

Steilen, M. (2011). The Democratic Common Law. Retrieved from: http://www.jurisprudence.com.au/juris10/Steilen.pdf.

Szczerbiak, A., Taggart, P. (2003). Theorising Party-Based Euroscepticism: Problems of Definition, Measurement and Causality. Sussex European Institute Working Paper, 69.

The Electoral Commission (2017). Retrieved from: https://www.electoralcommission. org.uk/find-information-by-subject/elections-and-referendums/upcomingelections-and-referendums/uk-general-election-2017.

Uberoi, E. (2015). European Union Referendum Bill 2015-2016. Retrieved from: researchbriefings.parliament.uk/documents/CBP-7212/CBP-7212.pdf.

Uberoi, E. (2016). European Union Referendum. Retrieved from: http://researchbriefings.files.parliament.uk/documents/CBP-7639/CBP-7639.pdf.

Usherwood, S. (2002). Opposition to the European Union in the UK: The Dilemma of Public Opinion and Party Management. Government and Opposition, 37(2), 211-230. DOI: 10.1111/1477-7053.00095.

Wallace, H. (2012). The UK: 40 Years of EU Membership. Journal of Contemporary European Research, 8(4), 531-546.

Wallace, W. (1991). Foreign Policy and National Identity in the United Kingdom. International Affairs, 67(1), 65-80. DOI: 10.2307/2621219.

Weatherill, S. (2016). The UK Referendum - Before and After. Cases and Materials on EU Law 12e. Retrieved from: http://global.oup.com/uk/orc/law/eu/eulaw/resources/ updates/.

Wistrich, E. (2001). Lessons of the 1975 Referendum. In: R. Beetham (ed.), The Euro Debate: Persuading the People (p. 37-47). London: Federal Trust for Education and Research. 